\title{
Is it Possible to Design a Math-Art I nstructional Practice? Cases of Pre-service Teachers
}

\author{
Işıkhan UĞUREL ${ }^{*} \quad$ Gökçe TUNCER ${ }^{* *} \quad$ Çağla TOPRAK $^{* * *}$
}

Received: 25 September 2012 Accepted: 13 September 2013

\begin{abstract}
To many people, establishing relationships between mathematics and art is difficult or surprising. However, these two disciplines are quite interrelated. Today, the literature of mathematics reveals that there has been an increasing interest in interaction between these two disciplines. As also observed in our country, the studies on relationships between mathematics and art have gained more popularity in mathematics education. There is a course entitled, "Mathematics and Art" offered as one of elective courses and taught for ten years to juniors of the Department of Secondary Mathematics Education, Dokuz Eylül University. The course covers a wide range of activities derived from relationships between mathematics and music to activities derived from those between mathematics and handicraft. In this study, cases of pre-service teachers attending this course were analysed. They were asked to do an instructional design integrating mathematics into art at secondary education level. Their designs were analyzed based on the use of art in which contexts and for what purposes. Furthermore, their designs were analyzed in terms of whether they enhance learning. This qualitative study had a case study design. The participants were 43 pre-service mathematics teachers voluntarily selected from students taking the course. Descriptive analysis was done to analyze the data. As a consequence of the analysis, math-art instructional practices developed by preservice teachers were clustered under three primary categories (good, average and inadequate). The majority of mathart instructional practices were categorized under the average category. In the study, these categories were described and cases in each category were discussed.
\end{abstract}

Keywords: mathematics, art, mathematics and art, pre-service mathematics teacher, mathematics education.

\section{Extended Abstract}

Today, a great number of researchers agree on that mathematics and art are interrelated with each other (Emmer, 1993; Graham, 1996; Hickman \& Huckstep, 2003). The past studies showed that mathematics is interrelated with many fields of art ranging from painting, music and sculpture to architecture, handicrafts and photography (Bora, 2002; Fukuda, Kanomata, Mutoh, Nakamura, \& Schattschneider, 2011; Karaçay, 2000; Orhan, 1995; Shilling, 2002; Wichmann, 2008).

Purpose and Significance: Today, it is seen that interaction between mathematics and art is not limited to research or theory. Its integration into practice through courses and teaching programs has already started. In many countries (e.g., UK, USA, France) all levels from primary education to higher education include instructional practices integrating mathematics into art (e.g., Bixler, 1980; James, 2011). Also, the principles and standards of the National Council of Teachers of Mathematics (NCTM) in 2000

\footnotetext{
* Corresponding Author:Assoc. Prof. Dr., Dokuz Eylül University, isikhan.ugurel@deu.edu.tr

${ }^{* * *}$ M. Sc. Student, Dokuz Eylül University, gkctncr@gmail.com

**** Mathematics Teacher \& M.Sc. Student, Dokuz Eylül University, cgl-tprk@gmail.com
} 
have emphasized many times the necessity to use art during mathematics education (NCTM, 2000). One of the primary objectives listed within secondary mathematics curriculum which was renewed in 2005-2006 and put into practice in 2011 is "to establish a relationship between mathematics and art and improve aesthetic feelings" (Ministry of National Education [MoNE], 2011a: 4). Also, it has been stated as one among 27 objectives of the secondary geometry curriculum (MoNE, 2011b: 7). So, there has been a strong demand for teachers who are able to discover and establish relationships between mathematics and art and do instructional practices integrating mathematics into art. One step to attain this objective is the course entitled, "Mathematics and Art" offered as one of elective courses and taught for ten years to juniors of the Department of Secondary Mathematics Education, Dokuz Eylül University. Within the content of course, the art-related topics closely relevant to mathematics such as handicrafts, golden mean, fractals, architecture, Islamic art, photography, music, Escher and his work, origami-krigami and painting are covered. Pre-service teachers were asked to do an instructional design integrating mathematics into art at secondary education level. In this study, instructional practices designed by pre-service teachers were analysed and the results were presented. Therefore, it was aimed to contribute to the field of Math-Art (MA).

Method: This study was conducted as a qualitative research. Content analysis was used to analyze the data. Bailey (1982) noted that there are four stages of document analysis such as sample selection, category generation, definition of units of analysis, and use of numericals. For this study, Bailey's approach was taken into consideration. The participants were 43 pre-service mathematics teachers voluntarily selected from students taking the course, Mathematics and Art. They have been attending courses in the Department of Secondary Mathematics Education during the research. The documents were instructional designs of pre-service teachers who were asked to integrate math into art in a 2-hour-session course based upon objectives of the secondary mathematics and geometry curriculum. They were asked to study individually and do their designs in two weeks before the end of the term. As noted by Bailey (1982), researchers preferred to generate their own categories. Initially, two of the researchers analyzed all documents independently and generated their categories on their own. Then, the researchers defined main categories and cases of pre-service teachers and compared their categories. Categories then reached their final forms. Instructional designs were decided to be clustered under three categories (good, average, inadequate).

Results: At the end of the analysis, instructional practices designed by pre-service teachers were clustered under three primary categories (good, average and inadequate). Most of the instructional designs were categorized under the average category, followed by the inadequate category and the good category. In each category, not all the instructional designs had common characteristics. For instance, some instructional 
designs under the average category aimed to motivate while a few aimed to associate math with art although art-related topics were chosen as appropriate to math-related topics. Besides, their educational aspect was lacking compared to those under the "good" category. The same case was valid for the "good" category. However, inability to integrate math into art caused 20 instructional designs under the "average" category. The main characteristic that distinguished instructional designs under the "good" category from those under the "average" category was integration of two disciplines into teaching. The main characteristic that distinguished the "inadequate" category from the other two categories was lack of quality of relations between MA topics. In other words, relationships between mathematics and art were ignored or not established in the "inadequate" category. Moreover, mathematical topics associated with art were also examined. It was seen that art-related topics used are golden mean, Escher and his work, fractals, Fibonacci series, concept cartoons, painting and architecture. However, preservice teachers did not benefit from topics such as handicrafts, origami-krigami, music, cinema, and photography. There were 14 mathematics topics with golden mean and fractals; 8 with Escher; 9 with concept cartoons; 6 with painting and 3 mathematics topics with Fibonacci series and architecture.

Discussion and Conclusion: At the end of the analysis, $16 \%$ of the instructional designs were found under the "good" category, 47\% under the "average" category and $37 \%$ under the "inadequate" category. Therefore, the majority of the instructional designs were under "average" and "inadequate" categories. It can be thought that preservice teachers chose art-related topics in order to make mathematics topics concrete and to draw attention. Although relationships between mathematics and art have been considered in the course, Mathematics and Art, it should be noted that some of the topics haven't been used at all showing pre-service teachers' lack of integration mathematics into art. According to the results, it is possible to say that knowledge of Mathematics and Art and discussions about Mathematics and Art can not contribute alone to designing high-quality instructional practices. Therefore, studies on the development, implementation and evaluation of various teaching practices and activities based directly on Mathematics and Art relationships are demanded apart from studies that give information about Mathematics and Art relationships and from discussions in both the Mathematics and Art course and other field courses at undergraduate level. 


\title{
Matematiği Sanatla İlişkilendiren Bir Öğretim Uygulaması Tasarlamak Mümkün müdür? Öğretmen Adaylarının Çalışma Örnekleri
}

\author{
Işıkhan UĞUREL ${ }^{*}$ Gökçe TUNCER ${ }^{* *}$ Çağla TOPRAK ${ }^{* * *}$
}

Makale Gönderme Tarihi: 25 Eylül 2012

Makale Kabul Tarihi: 13 Eylül 2013

\begin{abstract}
ÖZET: Birçok insan için matematik ve sanat arasında ilişki kurmak, zor ya da şaşırtıcı olabilmektedir. Ancak bu iki disiplin düşünülenin aksine birbiri ile oldukça ilişkilidir. Bugün matematik eğitimi literatüründe iki disiplin arasındaki etkileşim alanlarına yönelik ilginin giderek arttığı görülmektedir. Ülkemizde de matematik eğitimi alanında yaşanan gelişmeler kapsamında matematik ve sanat ilişkisine dayalı çalışmaların arttığı gözlenmektedir. Öğretmen yetiştirme süreci bu kapsamda ele alınabilecek çalışma alanlarından biridir. Dokuz Eylül Üniversitesi Ortaöğretim Matematik Öğretmenliği bölümü lisans programının üçüncü sınıf seçmeli dersleri arasında on yıldır yürütülen "Matematik ve Sanat" adlı bir ders yer almaktadır. Dersin konuları arasında matematik ve müzik ilişkisinden el sanatlarındaki matematiğe kadar geniş bir alana yönelik bir perspektif sunulmaktadır. Bu çalışmada bu dersi alan öğretmen adaylarının yılsonu çalışma örnekleri ele alınmaktadır. Söz konusu çalışmalar ortaöğretim düzeyinde matematik ve sanat entegrasyonuna dayalı bir öğretim uygulamasının içeriğinin planlanmasını içermektedir. Öğretmen adaylarının geliştirdikleri öğretim uygulamaları üzerine yapılan analizlerde sanat konularından hangi matematiksel içeriklerde ve ne tür amaçlarla yararlanıldığına bakılmıştır. Ayrıca, tasarımların (ele alınan matematik-geometri konusundaki kazanımlar çerçevesinde) öğrenmeyi gerçekleştirmeye yönelik olup olmadığı incelenmiştir. Çalışmada nitel araştırma yaklaşımına dayalı durum çalışması yöntemi kullanılmıştır. Katılımcılar dersi alan öğrenciler içerisinden gönüllük esasına göre seçilen 43 matematik öğretmen adayından oluşmaktadır. Yapılan tasarımlar betimsel analize tabi tutulmuştur. Analiz sonucunda adaylarca geliştirilen öğretim uygulamalarının üç (iyi, orta ve yetersiz) temel kategoride toplandığı görülmüştür. Yığılımın olduğu kategori ikincidir. Çalışmada bu kategoriler tanıtılmakta ve her bir kategoride yer alan örnekler tartışılmaktadır.
\end{abstract}

Anahtar sözcükler: matematik, sanat, matematik ve sanat, matematik öğretmen adayı, matematik eğitimi

\section{Giriş}

Matematik, kendi içyapısında sürekli gelişen bir disiplin olmasının yanı sıra, farklı birçok disipline hayat veren bir alan olma özelliğini de taşımaktadır. Matematiğin fizik, kimya, uzay bilimi gibi disiplinlere olan katkısı herkesçe biliniyor olmasına karşın, sanatla olan ilişkisi kimileri için ilk bakışta şaşırtıcı olabilmektedir. Eğer matematik ve sanata yönelik genel ve tek bir tanımlama yapma yoluna gidilirse (Matematik, biçim, sayı ve çoklukların yapılarını, özelliklerini ve aralarındaki bağıntıları mantık yoluyla inceleyen, aritmetik, cebir, geometri gibi dallara ayrılan bilim kolu" ve sanat ise "duygu, tasarı, güzellik vb. nin anlatımında kullanılan yöntemlerin tamamı veya bu anlatım sonucunda ortaya çıkan üstün yaratıcılı" (TDK, 2012) olarak tanımlanırsa) ilk bakışta iki disiplinin etkileşim içinde olduğunu fark etmek güçleşecektir. Ancak bu iki disipline yönelik bilgi ve deneyimler arttıkça belirli ilişkilendirmeleri yapmak mümkün olabilmektedir. Güneş ve Gökçek (2010), matematik ve sanat eğitimcilerinin iki disiplin arasındaki ilişki boyutuna bakış açılarını ortaya koyan çalışmalarında, sanat eğitimcilerinin matematiği katı ve esnek olmayan bir bilim olarak tanımladığını, ancak sanat eserlerinin ortaya çıkmasında matematikten

\footnotetext{
*Sorumlu Yazar: Doç. Dr., Dokuz Eylül Üniversitesi, isikhan.ugurel@deu.edu.tr

**Yüksek Lisans Öğrencisi, Dokuz Eylül Üniversitesi, gkctncr@gmail.com

${ }^{* * * *}$ Matematik Öğretmeni ve Yüksek Lisans Öğrencisi, Dokuz Eylül Üniversitesi, cgl-tprk@gmail.com
} 
yararlanıldığını da belirtmektedirler. Aynı çalışmada matematik eğitimcilerinin, matematiği sanat olarak gördükleri de ifade edilmektedir.

Matematik ve sanat arasındaki bağlantıları ve etkileşim alanlarını daha iyi kavramak için bu alana dönük araştırma isteğine gereksinim vardır. Nitekim pek çok araştırmacı matematik ve sanatın birbiriyle etkileşim içerisinde olduğunda hemfikirdir (Emmer, 1993; Graham, 1996; Hickman \& Huckstep, 2003).

Yapılan çalışmalar, matematiğin resimden müziğe, heykelden mimariye, el sanatlarından fotoğrafçılığa kadar birçok sanat dalı ile ilişkili olduğunu ortaya çıkarmıştır (Bora, 2002; Fukuda, Kanomata, Mutoh, Nakamura, \& Schattschneider, 2011; Karaçay, 2000; Orhan, 1995; Shilling, 2002; Wichmann, 2008).

Pek çok ülkede (İngiltere, Amerika, Fransa, vs.) matematik ve sanat dallarının arasındaki bu etkileşim göz önünde bulundurularak ilköğretimden yükseköğretim programlarına kadar her düzeyde, bu alana yönelik öğretim uygulamalarının yer aldığını görmek mümkündür (Bixler, 1980; James, 2011; Marino, 2008; McCoy, 1996). Ayrica, National Council of Teachers of Mathematics'in (NCTM) 2000 y1lında yayımladığ 1 prensipler ve standartlar içerisinde de birçok kez matematik öğretimi sürecinde sanattan yararlanılması gerektiği vurgulanmıştır. Bunlardan bir kaçı şu şekildedir; "matematiğin diğer alanlarla örneğin sosyal çalışmalar, fen, sanat ve fizik ĕgitimi arasındaki ilişki göz ardı edilmemelidir”, “Örneğin, geometri sanat için önemli bir rol oynar, veri sosyal araştırmalarda önemli bir etkiye sahiptir.” (NCTM, 2000: 44, 203).

Ülkemizde bir önceki matematik öğretim programlarında bu ilişki yeterince göz önünde bulundurulmazken, 2005-2006 y1llarında yenilenen ve 2011'de tekrar gözden geçirilip uygulamaya konan ortaöğretim matematik dersi öğretim programında sıralanan temel amaçlardan biri; “öğrencilerin matematik ve sanat ilişkisini kurabilmeleri, estetik duygularını geliştirebilmeleri" (Milli Eğitim Bakanlığı [MEB], 2011a: 4) biçiminde ifade edilmiştir. Ortaöğretim geometri dersi öğretim programının 27 genel amacından biri de bu amaç ile aynıdır (MEB, 2011b: 7). Özele indirgersek örneğin 11. sınıf geometri dersinin öğrenciye kazandırılacak 16 amacından biri şu şekilde ifade edilmiştir: "Geometride dörtgen, düzgün beşgen ve düzgün altıgen ile sanat arasında ilişki kurarak estetik duyguları geliştirmeleri" (MEB, 2011b: 12). Bu amacın örneğin çokgenler konusu işlenirken uygulamada nasıl hayata geçirileceğine yönelik etkinlik ipuçlarından biri Şekil-1'de sunulmuştur: 
Şekil 1. 11. Sınıf Geometri Dersi Öğretim Etkinliği İpucu

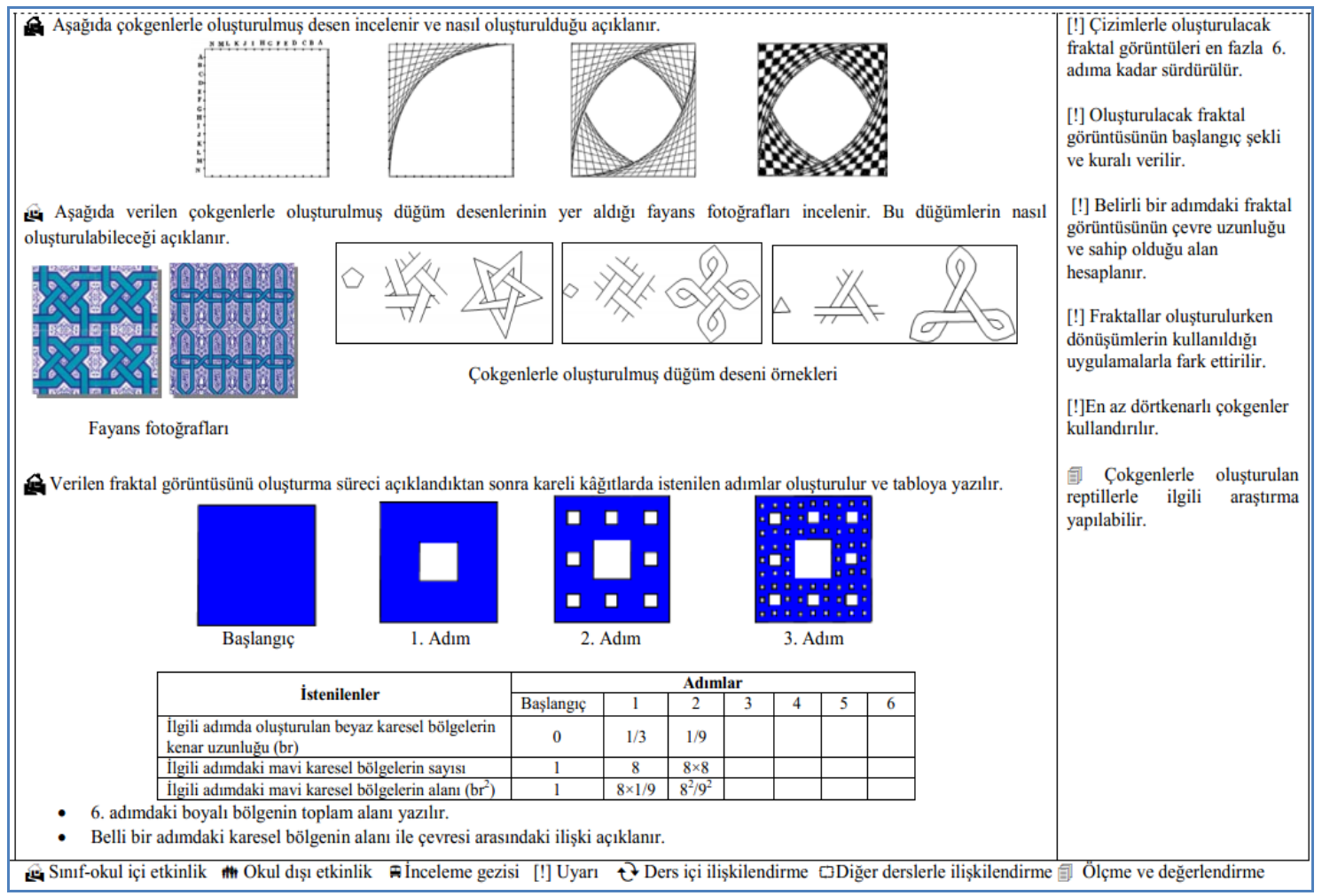

(MEB, 2011b: 61)

Öğrenciler, matematik ve sanat (MS) ilişkisine dayalı çalışmalarla ilk defa ortaöğretim seviyesinde karşılaşmamaktadır. İlköğretim matematik dersi öğretim programında da MS bağlantılarını içeren etkinlik örnekleri (örneğin; ilköğretim 1-5. sinıflar için 82, 83, 129, 176, 237, 297. sayfadaki etkinlikler (MEB, 2009a); 6-8. sinıflar için 167, 170, 287, 317. sayfadaki etkinlikler) (MEB, 2009b) yer almaktadır.

İki alan ilişkisine ortaöğretim görsel sanatlar dersi öğretim programında da pek çok yerde değinilmiştir. Örneğin; 10. sınıf programında "Türk Süsleme Sanatları" alt öğrenme alanının desen çalışmaları yine 10. sınıf matematik dersi cebir alt öğrenme alanıyla ilişkilendirilerek verilmektedir (MEB, 2009c: 103).

Görülüyor ki iki disiplin etkileşimini ele alan çalışmalar ilk ve ortaöğretimde hem matematik ve geometri hem de görsel sanatlar derslerinin öğretim programlarında fazlaca vurgulanmakta ve öğrenme uygulamalarına dönüşmektedir.

Öğretim programlarındaki anlayışa paralel olarak matematik ve sanat arasındaki ilişkileri keşfedebilen, kurabilen ve bu alanda öğretimsel uygulamalar gerçekleştirebilen öğretmenlere gereksinim olduğu açıktır.

$\mathrm{Bu}$ özelliklere sahip öğretmenlerin yetiştirilmesi amacıyla ülkemizdeki bazı matematik öğretmenliği bölümlerinde lisans düzeyi öğretim programları içerisine MS ilişkilerini barındıran dersler konulduğu görülmektedir (Örneğin; Karadeniz Teknik Üniversitesi Orta Öğretim Matematik Öğretmenliği [OMT] "Fraktallar", Başkent 
Üniversitesi İlk Öğretim Matematik Öğretmenliği [İMT] “Origami”, Gazi Üniversitesi İMT ve OMT “Kağıt Katlama ve Matematik”).

Sözü edilen üniversitelerden biri de Dokuz Eylül Üniversitesi'dir. Bu üniversitenin Ortaöğretim Matematik Öğretmenliği lisans programının üçüncü sınıf seçmeli dersleri arasında on yıldır yürütülen "Matematik ve Sanat" adlı bir ders yer almaktadır. Dersin konuları, seçen öğrenci sayısı ve öğrencilerle yapılan oturumlar sonrasında öğretim üyesi tarafından önerilen konular arasından seçilmektedir. Genel hatları ile MS dersinin amacı ve içeriği aşağıdaki biçimde özetlenebilir:

- Matematik ve sanat arasındaki ilişkileri kavrayabilme,

- Matematiğin sanat ve sanat eserleri üzerindeki etkisini fark etme,

- Matematik dersi öğretim programlarının sanat ile olan ilişkisini kavrama,

- Matematik ve sanatın etkileşim alanlarına yönelik araştırma yapabilme ve sunum hazırlayabilme,

- Matematik ve sanat entegrasyona dayalı öğretim uygulamaları geliştirebilme.

Ders, 16 haftalık bir dönemde 2 hafta dönem içi ve dönem sonu sınavlarına ayrılmış olup 14 haftada her hafta farklı bir sanat konusu ya da sanatla ilişkili bir konu işlenerek sürdürülmektedir. İlgili öğretim elemanınca, ilk hafta matematik ve sanata yönelik tanımlar, nitelemeler ve matematik dersi öğretim programındaki sanata yönelik içerikler; ikinci hafta Mathart'ın (matematiksel sanat) ne olduğu ve Mathart kapsamında çalışmalar yapan önemli Türk ve diğer ülke sanatçılarının ("matematiksel-sanatçılar") kısa yaşam öyküleri ve eserleri sunulmaktadır. Üçüncü hafta "fraktallar" ele alınmakta, fraktal yapılar ve bu özellikteki yapıların örnekleri sunulmaktadır. Dördüncü ve beşinci haftalarda matematik ve resim ilişkisi incelenip ünlü resim sanatçılarının bazılarının (Da Vinci, Dürer, Escher...) eserlerindeki matematiksel ögeler, resimdeki birtakım perspektif çalışmaları, altın oran örnekleri ve barındırdıkları matematiksel özellikler sunulmaktadır. Altıncı hafta; Arşimet'in müziğe katkıları, müzik eserlerindeki altın oran, enstrüman yapımında ve müzikteki ses yapılarında matematik modellemelerine bakılarak matematik-müzik ilişkisi incelenmektedir. Yedinci hafta özel olarak Mimar Sinan'ın eserleri ve Mısır piramitleri ele alınıp mimari eserlerdeki matematik incelenerek mimaride de altın oran konusuna değinilmektedir. Sekizinci hafta arasınav haftasıdır. Dokuzuncu haftada sinema ve dijital sanatlardaki (fotoğraf) matematiksel unsurlar ve matematik ile ilgili sinema filmlerinin içerik ve eleştirileri üzerine tartışmalar gerçekleştirilmektedir. Onuncu ve on birinci haftalarda ise halı ve kilimlerdeki matematik (motif, desen, dönüşümler ve simetri), çini ve mozaik sanat eserleri, takı tasarımı, taş ve ahşap oymacılığ çerçevesinde matematiğin el sanatları ile ilişkisi incelenmektedir. On ikinci hafta origami / krigaminin tarihsel gelişimi ve örnekleri, eğitimde bunlardan yararlanma alanları tanıtılmaktadır. On üçüncü hafta matematik ve mizah ilişkisi, karikatürlerle matematik öğretimi, kavram karikatürünün kullanım alanları ve örnekleri sunulmaktadır. On dördüncü hafta İslam sanatındaki matematiksel ögeler ve yapıtlardaki özelllikler incelenmektedir. Ayrıca, her hafta ilgili konunun matematik 
öğretimine yansımaları ve uygulama örneklerinin araştırılması ve tartışılması istenmektedir. Konuların sırası ve derinliği dersi alan öğrencilerin ilgi, istek ve çalışmalarına göre değişiklik gösterebilmektedir.

Konulardan bazıları doğrudan sanata ait konular olarak değerlendirilemeyebilir (Örneğin; fraktallar, kavram karikatürü, altın oran). Ancak bu konular, matematiğe olduğu kadar sanata ait özelliklere ve içeriklere de sahip olup MS ilişkisinin çeşitli örneklerini içermektedir. Ayrıca, bu konular günlük yaşamda karşılıkları olan ve öğretimsel uygulamaları bulunan alanlardır. Bunlardan örneğin fraktalların matematik konusu olmasının yanı sıra sanat konusu olarak ele alınmasındaki amaç, doğadaki bir çok yapıda bulunuyor olması ve bu yapıların çeşitli iş sahalarında (örneğin; sismoloji, sinyal işleme, bilgisayar grafikleri) kullanılması ve görsel olarak estetik bir zenginlik sağlamasıdır. Benzer şekilde mizah da güldürürken düşündüren bir sanat dalı olarak görülmektedir (Özcan, 2002). Mizah; hikâye, fikra gibi edebi eserlerde yer almasının yanı sıra karikatürlerde de yer almaktadır. Karikatürler, "insan ve toplumla ilgili her tür olayı konu alarak abartılı bir biçimde veren, düşündürücü ve güldürücü resim” (TDK, 2012) biçiminde tanımlanmaktadır. Kavram karikatürleri ise, her bir karikatür karakterinin günlük yaşamdaki bir olaya ilişkin farklı bakış açılarını savunduğu ilgi çekici ve şaşırtıcı karikatür biçimindeki çizimlerdir (Keogh \& Naylor, 1999, aktaran İnel, Balım, \& Evrekli, 2009: 3). Yoong (2001)'e göre mizah ile matematik yapmak matematiği daha kolay, kullanışlı, anlamlı ve günlük hayatta kullanılabilir kılmaktadır (Uğurel \& Moral1, 2006). Benzer şekilde Fibonacci sayıları, altın oran da anlatılan ve incelenen içerik itibariyle sanatla yakından ilişkili olarak kabul edilmiştir.

Ders kapsamında yukarıda hafta hafta siralanan konuların sunumu sonrasinda öğretmen adaylarına dönem sonu çalışması olarak matematik ve sanat konularının entegrasyonuna dayalı bir ders tasarımı yaptırılmaktadır. Her hafta farklı sanat dallarının matematikle ilişkisinin irdelendiği göz önünde bulundurularak, tasarlanan ders planında sanatla ilgili konuları öğretmen adayının belirlediği matematik veya geometri konusuna entegre etmesi istenmiştir. Tasarımlarda geliştirilen etkinliklerin ve kullanılan materyallerin, matematik-geometri konusundaki kazanımların öğrenilmesini sağlamaya yönelik olması istenmiştir. Öğretmen adaylarından ayrıca özgün tasarımlar geliştirmeleri talep edilmiştir. Hem matematik konularının hem de sanatla ilişkili konuların seçiminde (sınıf seviyesi, kaç konu ile ilişkili olacağı, hangi araç-gereçlerin kullanılacağı, vb.) öğretmen adaylarına istedikleri gibi planlama ve uygulama yapabilecekleri söylenmiştir.

\section{Matematik Eğitiminde Matematik-Sanat İlişkisine Dayalı Çalışmalar}

Martinello (2000), “geleneksel disiplin merkezli öğretim programlarındaki ayrılık ve parçalanmışlıktan birlik ve bütünlüğü vurgulayan, disiplinler arası anlayıştaki öğretim programına yöneliş olduğunu” söylemektedir (Aktaran: Özkök, 2005: 159). Priolo (2009), ilköğretim 4. sınıf öğrencileriyle disiplinler arası anlayışa göre yürüttüğü çalışmasında, bir sanat konusuyla matematik öğretimi yapıldığında öğrencilerin matematiksel bir beceriyi kazanıp kazanmadığını ön test-son test ölçme tekniğiyle araştırmıştır. Araştırma sonuçları kontrol grubundaki öğrencilerin matematiksel 
becerilerinde çok önemli bir gelişme olmadığını göstermiştir. Ancak öğrencilerle yapılan görüşmelerde, öğrenme sürecinde kendilerini daha iyi hissettiklerini ve matematik dersine yönelik motivasyonlarının çok daha yükssek olduğu görülmüştür. Heally (2004), 10-14 yaş grubu öğrencilerin matematiğe karşı tutumlarında görsel sanatların etkisini araştırmıştır. Üç sömestr boyunca dönüşümlerin ve simetri konularının, MS entegrasyonuna dayalı olarak, Escher'in resimlerinden yararlanılarak ele alındığı bir çalışma yürütmüştür. Çalışma sonucunda öğrencilerin bilişsel ve sosyal yönden gelişimlerinde olumlu değişimler gözlenmiştir. Katılımcılar bu şekilde hazırlanan materyallerin daha çekici ve ilginç olduğunu düşünmüş ve matematik dersine karşı olumlu tutum göstermişlerdir. Üniversite düzeyinde yapılan çalışmalardan Kaplan ve Salesin (2004) geometrik İslami yıldız desenlerini araştırdıkları çalışmalarında Arapça yıldız anlamına gelen "Najm" adında bir araç geliştirmişlerdir. Bu araç, İslami yıldız desenlerinin oluşturulmasında keşif için geometri aksiyomları oluşturmaktadır. $\mathrm{Bu}$ sayede oluşturulan yıldız desenleri Öklid düzlemine, hiperbolik düzleme veya kürenin yüzeyine uygun şekilde dizayn edilebilmiştir. Teorik üniversite matematiğinin özellikle soyut cebir dersindeki simetrik gruplar konusunun uygulama alanı olduğunu göstermişlerdir. Bu tür örnekleri ele alan başka çalışmalar da bulunmaktadır (Örneğin; Boakes, 2009; Farako \& Francaviglia, 2004; Hanson, 2002; Karakuş, 2010; Kelley, Jordan, \& Roberts, 2001).

Görülüyor ki bu iki disiplin entegrasyonuna dayalı her düzeyde öğrenciye öğretim uygulaması hazırlanabilmekte, öğrenciler ve öğretmenler açısından değerlendirildiğinde olumlu dönütler alınabilmektedir.

$\mathrm{Bu}$ çalışmada ise, öğretmen adaylarının MS ilişkisine dönük tasarladıkları öğretim uygulamaları ele alınmış, bunlar üzerinde yapılan analiz sürecinde sanat konularından hangi matematiksel içeriklerde ve ne tür amaçlarla yararlanıldığına bakılmıştır. Böylece MS'ye dönük katkı yapılması amaçlanmaktadır.

Araştırmamızda ele alınan problem, "Öğretmen adaylarının MS dersi kapsamındaki öğretimsel tasarımlarında sanatla matematiği ilişkilendirmeleri ne düzeydedir?" biçimindedir. $\mathrm{Bu}$ problem altında sanatı, oluşturulan tasarım etkinliklerinde öğrenmeye dönük olarak kullanıp kullanmadıklarına bakılmıştır. Ayrıca, tasarımlarda hangi sanat dallarının hangi matematik-geometri konularında kullanıldığı da incelenmiştir.

\section{Yöntem}

$\mathrm{Bu}$ çalışma nitel araştırma yaklaşımı ile gerçekleştirilmiştir. Nitel araştırma desenlerinden durum çalışmasından faydalanılmıştır. Durum çalışması (örnek olay), güncel bir olguyu kendi yaşam çerçevesi içinde çalışan ve birden fazla veri kaynağının mevcut olduğu durumlarda kullanılan araştırma yöntemidir (Yin, 1984). Çalışmada katılımcıların ders tasarım örnekleri üzerinde doküman incelemesi yapılmıştır. "Doküman incelemesi, araştırılması hedeflenen olgu veya olgular hakkında bilgi içeren yazılı materyallerin analizini kapsar" (Yıldırım \& Şimşek, 2008: 187). Bailey (1982), dokümanların temel ya da tek veri seti olduğu araştırmalarda genel izlence olarak 4 
aşamanın olduğundan söz etmektedir. Bunlar; analize konu olan veriden örneklem seçme, kategorilerin geliştirilmesi, analiz biriminin saptanması ve (mutlak olmamakla birlikte) sayısallaştırma biçimindedir. Bu çalışmada ana hatlarıyla Bailey'in yaklaşımı esas alınmıştır.

\section{Katılımcilar}

Araştırma MS dersini alan ve çalışmaya gönüllü katılan 43 öğretmen adayı üzerinde gerçekleştirilmiştir. Bu kişiler araştırmanın yapıldığı süreçte Dokuz Eylül Üniversitesi, Buca Eğitim Fakültesi, Ortaöğretim Matematik Öğretmenliği lisans programının 3. sınıfında öğrenim görmektedir. MS dersini alan toplam 56 öğrenci bulunmaktadır. Ancak bunlardan 13'ü yılsonu çalışmalarının bu araştırma kapsamında değerlendirilmesine izin vermediği için çalışmada 43 kişinin dokümanları kullanılmıştır. Araştırmanın örneklemi, amaçlı örnekleme yöntemi kullanılarak oluşturulmuştur. Amaçlı örnekleme, zengin veya çeşitli bilgiye sahip olduğu düşünülen durumların derinlemesine çalışılmasında, olgu ve olayların keşfedilmesinde ve açıklanmasında yararlı olmaktadır (Patton, 1987, aktaran Yıldırım \& Şimşek, 2008). Katılımcıların 28'i bayan, 15'i erkektir. Adayların tümü dersi ilk kez almıştır.

\section{Veri Toplama}

$\mathrm{Bu}$ çalışmanın verileri olan dokümanlar, MS dersini alan öğretmen adaylarının iki disiplinin entegrasyonuna dayalı öğretim uygulaması tasarım örnekleridir. Öğretim uygulamalarının tasarlanma sürecindeki kuramsal zemin “disiplinler arası yaklaşım” dır. Disiplinler arası yaklaşım, "bir kavramın, konunun, problemin ya da tecrübenin incelenmesi için birden fazla disiplinin yöntem ve dilini bilinçli bir şekilde uygulayan program anlayışıdır" (Jacops, 1989: 8). Aybek (2001)'e göre bu yaklaşım, "öğretim ortamına canlılık kazandırma, öğrencilerin yaratıcılıklarını kullanmalarını sağlama ve en önemlisi de onları derslere karşı ilgili olmaya teşvik edip öğretmeyi garanti etme açısından büyük önem taşımaktadır" (Aktaran: Demirel, Tuncel, Demirhan \& Demir, 2008: 16). Disiplinler arası yaklaşım konusunda literatürde, farklı disiplin alanları arasındaki ilişkilerin çeşitliliklerini ifade eden bir dizi terimle karşılaşılmaktadır. Bunlar; çapraz-disiplinler (Crossdisciplinary), çok-disiplinli (Multidisciplinary), çoğulcu-disiplinler (Pluridisciplinary), disiplinler-ötesi (Transdisciplinary) dir (Jacops, 1989). Bu çalışmada ise sözü edilen kavramlardan "çapraz-disiplinler" anlayışı göz önüne alınmıştır. Meeth (1978) çapraz-disiplinler kavramını, "bir disipline başka bir disiplinin bakış açısıyla bakılması olarak açıklamıştır" (Aktaran: Jacops, 1989: 8). Çalışmalarda ortaöğretim matematik dersi öğretim programındaki konulara sanat konularının entegrasyonu bakış açısıyla bakılmaya çalışılmıştır. Öğretmen adaylarının tasarladıkları ders örnekleri aracılığıyla, MS dersi içerisinde bilgi edindikleri sanatla ilişkili konuları matematik öğretimine ne şekilde aktarabildikleri belirlenmeye çalışılmıştır. Bu yaklaşım altında öğretmen adaylarından, yürürlükte olan ortaöğretim matematik ve geometri dersi öğretim programları çerçevesinde, kendilerinin seçecekleri kazanımlara uygun en fazla iki ders saatini $(45+45)$ içeren bir öğretim uygulaması tasarlamaları istenmiştir. Adaylardan bir yarıyıl süresince işlenen MS dersinde tüm 
konuların tamamlanmasından sonra iki haftalık süre zarfında tasarımlarını bireysel olarak oluşturmaları talep edilmiştir. Veriler yazılı olarak hazırlanan ders tasarımlarından oluşmaktadır.

\section{Analiz}

Analize yönelik olarak Bailey (1982), kategorilerin geliştirilmesinde var olan kuram ve yaklaşımlardan yararlanılabileceği gibi araştırmacıların kendi kategorilerini oluşturmayı tercih edebileceklerini de belirtmiştir. Bu çalışmanın yazarları kendi kategorilerini geliştirme yolunu seçmiştir. İlk aşamada üç araştırmacıdan ikisi birbirinden bağımsız olarak tüm dokümanları incelemiş ve her biri kendi kategorilerini oluşturmuştur. Akabinde bu araştırmacılar biraraya gelerek belirledikleri kategorilerin temel özellikleri ve örneklerini tanımlayıp kategorileri karşılaştırmışlardır. Genel itibariyle benzer kategoriler belirlenmiş olup aynı ya da benzer özellikleri içeren ve örneklendirmesi benzer olan kategorilere ortak isimlendirme yapılarak her bir kategorinin özellikleri sıralanmıştır. Daha sonra öğretmen adaylarının çalışmalarından rastgele seçilen 15 örnek, diğer yazar tarafından oluşturulan kategorilere göre kodlanmış ve bu yolla kategorilerin güvenirliği yoklanmıştır. Kodlayıcı güvenirliği ise farklı kodlayıcıların aynı veriyi aynı veya benzer şekilde kodlamalarıyla mümkündür (Bilgin, 2006). Bu aşamada üçüncü yazarın 15 çalışmanın 12'sini diğer iki yazarın belirlediği biçimde kodladığı üç tanesinde ise kararsızlık yaşadığı görülmüştür. "Görüş birliği” ve "görüş ayrılığı" olan örnekler üzerinde tartışılarak ortak bir karara varılmıştır. Miles ve Huberman (1994)'ün önerdiği güvenirlik formulü [(12/15).10] ile \%80 oranında görüş birliğine varılmıştır. Güvenirlik yüzdesinin $\% 80$ ve üzerinde elde edilmesi, araştırma için güvenilir kabul edilmektedir (Büyüköztürk, 2011; Miles \& Huberman, 1994). Kodlamadaki benzerlik oranının fazla olması kodlayıcı güvenirliği açısından yeterli bulunmuştur. $\mathrm{Bu}$ aşama sonrası kategorizasyona son şekli verilerek geliştirilen öğretim uygulamalarının üç (iyi, orta ve yetersiz) kategori altında ele alınmasına karar verilmiştir. Bu kategoriler ve onlara ait göstergeler Tablo 1'de sunulmaktadır. Yani kategoriler, incelenen öğretim uygulamaları sonucunda oluşturulmuştur. Örneğin; sanat konularıyla matematik konuları amaçlarına uygun şekilde entegre edilerek uygulamaya yansitıldığında ve ilişkilendirmede öğrenme amaçlı kullanıma ağırlık verildiğinde bu öğretim uygulaması, “iyi” kategorisinde ele alınmıştır. Analiz sürecinde katılımcıların gerçek isimleri kullanılmamış, bunun yerine her öğretim uygulamasına bir numara verilmiştir. Kategorilerin ve göstergelerin oluşturulması sonrasında üç yazar tek bir oturumda tüm öğretim uygulamalarını baştan sona incelemiş ve tüm öğretim uygulamalarının hangi kategoride yer aldıklarını belirlemiştir. Bu aşamada üç yazarın da uzlaşması sağlanıncaya kadar tartışma ve inceleme süreci sürdürülmüş, her bir doküman bu şekilde kategorilere göre sınıflandırılmıştır. 
Tablo 1

Kategoriler ve Açıklamaları

\begin{tabular}{|c|c|}
\hline $\begin{array}{l}\text { Matematik konusu ile } \\
\text { kurulan ilișkinin düzeyi }\end{array}$ & Göstergeler \\
\hline \multirow{3}{*}{ İyi } & $\begin{array}{l}\text {--Sanat konularıyla matematik konularını amaçlarına uygun şekilde entegre } \\
\text { ederek uygulamaya yansıtabilmek. }\end{array}$ \\
\hline & $\begin{array}{l}\text {--İki ve daha fazla sanat konusunu, matematik konusuyla zengin şekilde } \\
\text { ilişsilendirebilmek. }\end{array}$ \\
\hline & --İlişkilendirmede öğrenme amaçlı kullanıma öncelik / ağırlık vermek. \\
\hline \multirow{4}{*}{ Orta } & $\begin{array}{l}\text {--Sanat konusunu matematik konusuna uygun seçmek. Fakat, } \\
\text { a) sadece motivasyon sağlamak (dikkat çekmek) amacıyla yararlanmak. } \\
\text { b) doğrudan bilgi vermek amacıyla yararlanmak }\end{array}$ \\
\hline & -- Matematik konusunun öğretiminde bir veya iki sanatla ilişkili konudan \\
\hline & --Seçilen sanat konusundan amaca yönelik yararlanabilmek. \\
\hline & --Seçilen sanat konularına öğretimde gereğinden fazla yer ayırmak. \\
\hline \multirow{4}{*}{ Yetersiz } & --Sanat konuları ile matematik konuları arasındaki ilişkiyi kuramamak. \\
\hline & $\begin{array}{l}\text {--Sanat konusunu matematik konusundan bağımsız ve farklı amaçlarla } \\
\text { (örneğin; sadece anlık dikkat cekmek icin) ele almak. }\end{array}$ \\
\hline & --Sanatla ilgili sadece bir konuyu seçmek. \\
\hline & $\begin{array}{l}\text {--Seçilen sanat konusundan matematik öğretiminde uygun şekilde } \\
\text { yararlanamamak. }\end{array}$ \\
\hline
\end{tabular}

Bailey (1982), temel kategorilerin oluşturulması sonrasında analiz biriminin belirlenmesinden söz etmektedir. Araştırmanın amacı, problemi ve verilerin niteliğine bağlı olarak farklı birimlerin tercih edilmesi söz konusudur. Bizim çalışmamızda analiz birimi 'içerik' tir. Sanat konularından hangi matematiksel içeriklerde ve ne tür amaçlarla yararlanıldığına bakılmıştır.

\section{Bulgular ve Yorum}

\section{Öğretmen Adaylarının Ders Tasarımlarında Sanat Konularıyla Matematiği İlişkilendirme Düzeyleri}

Analizin açıklandığı bölümde belirtildiği gibi öğretmen adaylarınca geliştirilen öğretim uygulamaları üç temel kategoride (iyi, orta, yetersiz) dağılım göstermiştir. Bu kategorilerde yer alan çalışmalar ve frekansları Tablo 2'de gösterilmiştir.

Tablo 2

Tasarlanan Öğretim Uygulamalarının Kategorilere Göre Dă̆ılımı

\begin{tabular}{ccc}
\hline Kategori & $f$ & Uygulama Numaras1 \\
\hline İyi & 7 & $14,23,25,26,28,32,34$ \\
Orta & 20 & $1,2,3,5,8,10,11,12,18,21,24,27,29,31,33,37,39,41$, \\
& & 42,43 \\
Yetersiz & 16 & $4,6,7,9,13,15,16,17,19,20,22,30,35,36,38,40$ \\
\hline
\end{tabular}

Tabloda görüldügü üzere hazırlanan ders tasarımları en fazla orta kategorisinde yer almıştır. Onu yetersiz ve iyi kategorileri izlemiştir. Her bir kategoride tüm 
çalışmalar birebir aynı özellikleri taşımamakla birlikte ortak özellikleri barındırmaktadır. Örneğin; 'orta' kategorisinde incelenen ödevlerde, sanat konusu matematik konusuna uygun olarak seçildiği hâlde birini diğeriyle ilişkilendirme aşamasında, bazılarında motivasyon sağlama $(5,8,18,41)$, bazılarında ise doğrudan bilgi verme $(12,21,33,39)$ amacı esas alınmıştır ve öğretimsel yön, iyi kategorisine göre, daha azdır. Uygun seçim olarak ifade edilen şey, sanatla ilişskili konunun içeriğinin, matematik konusunun öğrenilmesine yönelik doğru biçimde yani, öğrenmeyi destekleme veya sağlama amaciyla seçilmesi durumudur. Aynı durum iyi kategorisindeki çalışmalar için de geçerlidir fakat yapılan seçimin tam manasıyla uygulamaya dökülememesi orta kategorisinde değerlendirilen 20 çalışmanın eksik kalan tarafını oluşturmuştur. $\mathrm{Bu}$ durumu örneklendirecek olursak aşağıdaki tasarımda (Resim 1) diziler konusu ele alınırken Fibonacci dizisi örnekleri sunulmuştur. Burada sanat konusu olarak altın oran ve mimari, matematik konusu olan dizilere uygun olarak seçilmiş, ancak Fibonacci dizisinin günlük hayatta bazı nesneler üzerinde etkisinin görülebileceği sadece sözel olarak ifade edilmiş, öğrencinin örneklere yönelik dikkati çekilmeye çalışılmış ve kavramsal öğretime kısıtlı katkı sağlanmıştır.

Resim 1. Orta Kategorisi, 11 Numaralı Öğretim Uygulaması

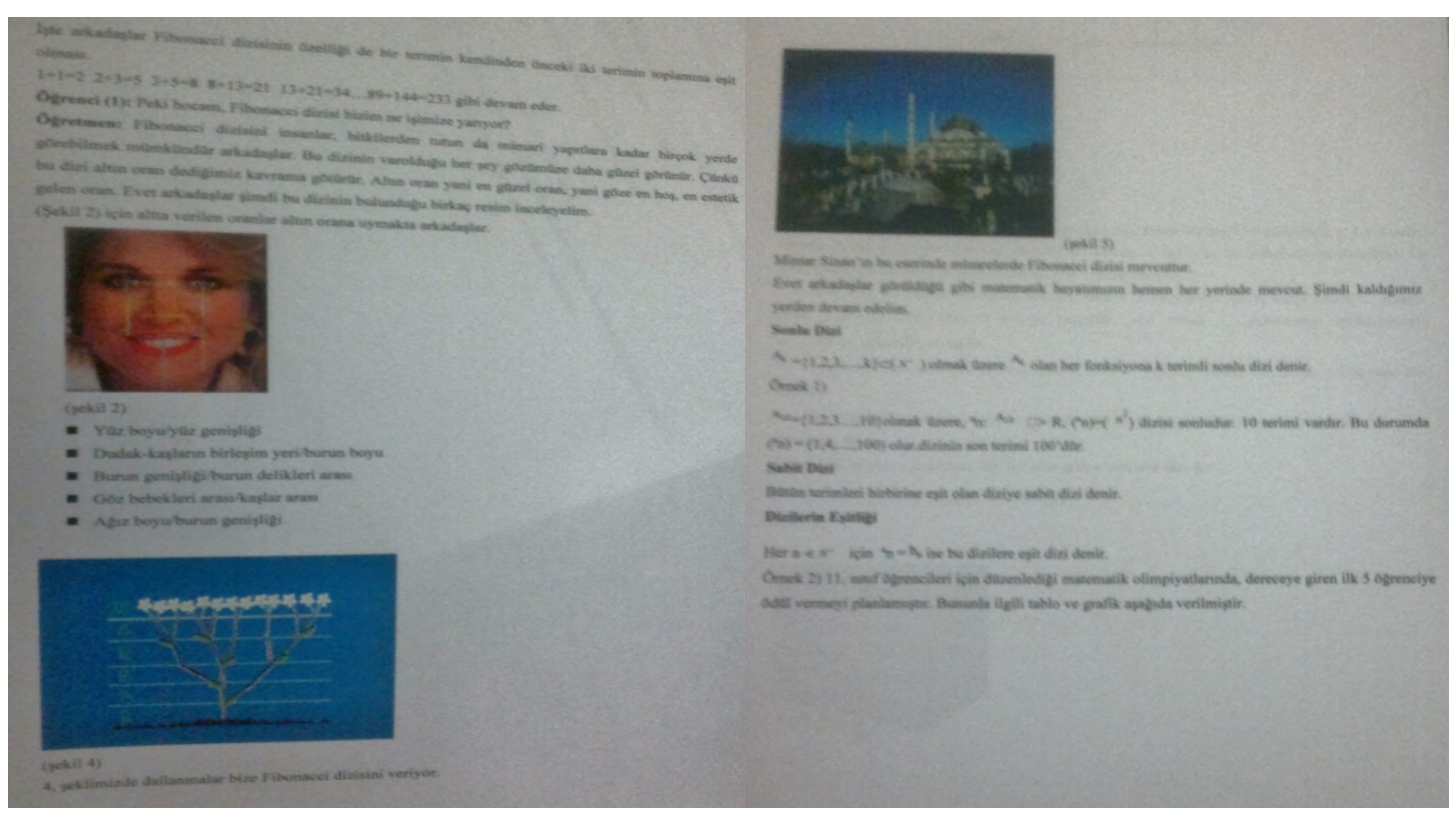

$\mathrm{Bu}$ kategorinin bir diğer özelliği, genel itibariyle uygulamalarda bir veya iki sanat konusunun seçilmiş olmasıdır. Ancak bazı çalışmalarda (örneğin; 41 numaralı öğretim uygulaması-doğal sayılar konusu-için sanatla ilişkili alanlardan fraktal, altın oran, Escher ve sanatı seçilmiştir) ikiden fazla sanat konusu seçilmiş olmasına karşın öğrenme uygulamasında iki alanın doğru şekilde entegre edilememesi, öğretim uygulamasının orta kategorisinde yer almasına neden olmuştur.

'İyi' kategorisinde incelenen çalışmaları 'orta' kategorisindekilerden ayıran temel özellik, iki alanı ilişkilendirmenin zengin bir şekilde öğretim uygulamasına 
yansitılmasıdır. Aşağıda verilen ve iyi kategorisinde değerlendirilen 26 numaralı öğretim uygulamasında matematik konusu olarak geometrik diziler seçilmiştir (Resim 2). İlk olarak öğrencilerin hem konuya dikkatini çekmek hem de öğrenciyi düşündürmek amacıyla kavramın uygulama alanını içeren bir kavram karikatürü kullanılmıştır. Daha sonra konuya giriş yapılarak, geometrik dizilerin önemli örneklerinden biri olan fraktalların sanatsal bir görüntüsüyle öğrencinin farklı bir uygulama alanı görmesine zemin hazırlanmıştır. Görüntüden hareketle Mandelbrot’un İngiltere sahillerinin kıyı boyu uzunluğunu ölçmek için oluşturduğu düşünce ile kavramsal düzeye giriş yapılmış, sonrasında Sierpinski kalburu aracılığıyla geometrik dizi anlatılarak akabinde örnek bir soru çözülmüştür. Bu aşamanın ardından Mozart'ın müziğinde mükemmel oranların bulunduğu söylenerek bu denli akılda kalıcı ve zevk verici tadın altında matematiksel bir yan olabileceğine değinilerek, ders 'Hallelujah' adlı eser ile sonlandırılmıştır. Dolayısıyla geometrik diziler konusunun işlenişinde sanatla bağlantılı konularla ilişkilendirmesi hem görsel hem de teorik olarak uygun şekilde yapılabilmiştir.

Resim 2. İyi Kategorisi, 26 Numaralı Öğretim Uygulaması

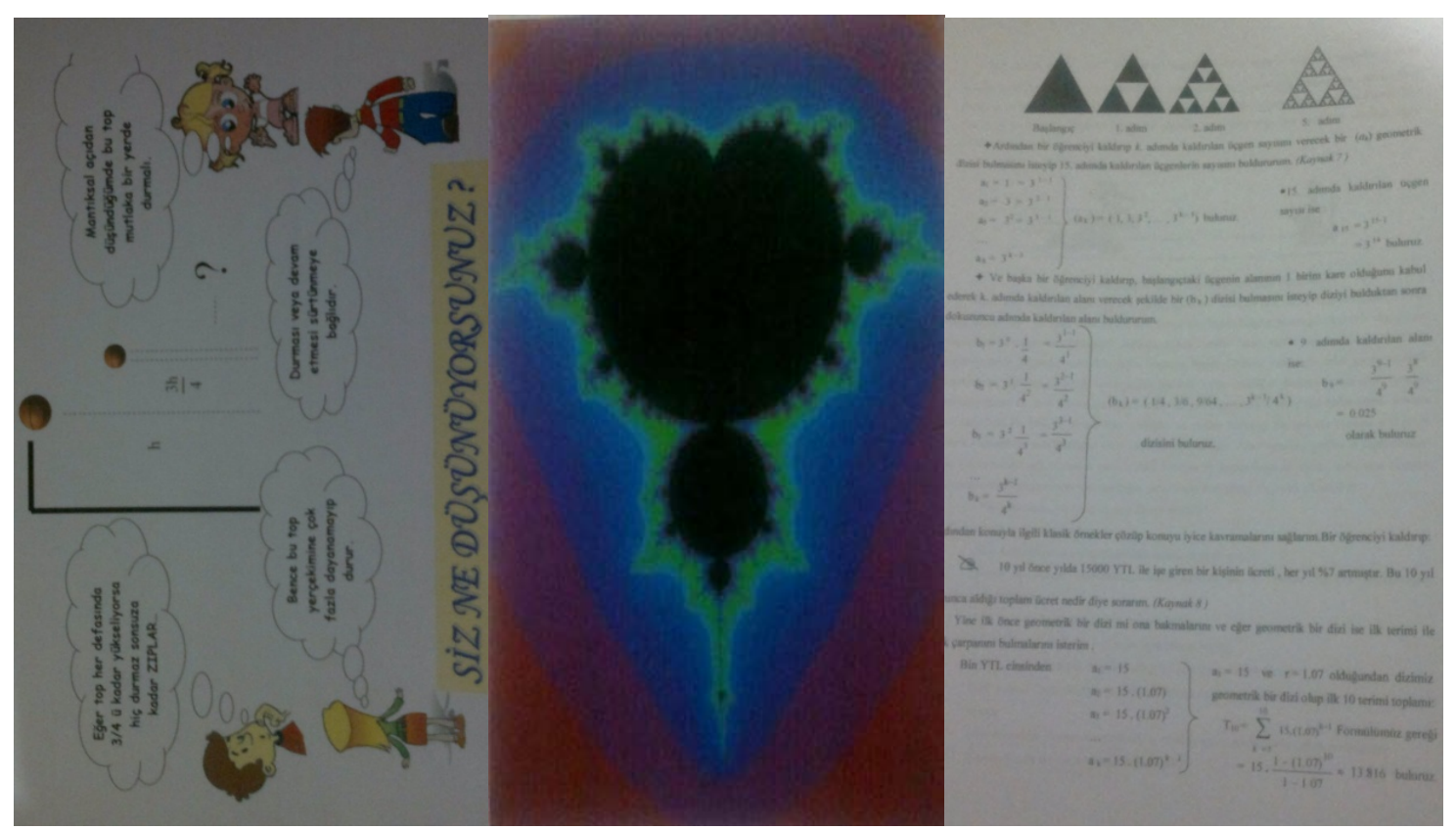

$\mathrm{Bu}$ sayede, öğrenciler tarafindan hep yakınılan matematiğin nerede kullanıldığına dair soruların basit bir cevabı da sezdirilmiş, öğrencilerin matematik dış1 alanla matematiği ilişkilendirmede bir yol oluşturulmaya çalışılmıştır. Verilen örnekler, hem tasarım içerisindeki akışın uygun / doğru bölümleri hem de matematiksel içerik ile uyumlu oldukları için matematiksel düşünme, akıl yürütme ve ilişkilendirme becerilerinin gelişmesine hizmet eder yapıda bulunmuştur. İki alanın bu şekilde ilişkilendirilerek konu bütünlüğünü bozmayacak şekilde verilmesi, bir alanın diğer alanda kavramsal öğrenmeye yardımcı olması ve öğrenci-öğretmen motivasyonunu artırmaya yönelik olumlu bir girişimin olması bu kategorideki öğretim uygulamalarının 
artı yönünü oluşturmuştur. Ayrıca, bu öğretim uygulamasında fraktalların yanı sıra Escher ve sanat1, kavram karikatürü ve müzik olmak üzere sanatla ilişkili dört alanın harmanlanması ilişkilendirme boyutunu güçlendirmiştir. $\mathrm{Bu}$ yönü ile bu kategorideki diğer altı çalışmayla da (iki veya daha fazla sanat konusu tercih etme) ortak özelliğe sahiptir.

'Yetersiz' kategorisini diğer iki kategoriden ayıran ana unsur, buradaki çalışmalarda MS konuları arasında öğrenme açısından nitelikli bir ilişki kurulamamış olmasıdır. Başka bir ifadeyle, bu kategorideki çalışmalarda öğrenme uygulaması hazırlanırken dikkat edilmesi gereken noktalardan biri olan matematiksel içerikle sanat konusunun kullanılma amacının birbirini desteklemesi gerekliliği göz ardı edilmiştir ya da başarılamamıştır. Bu nokta, çalışmaları orta ve iyi kategorisinden ayıran temel özelliktir.

Resim 3. Yetersiz Kategorisi, 7 Numaralı Öğretim Uygulaması
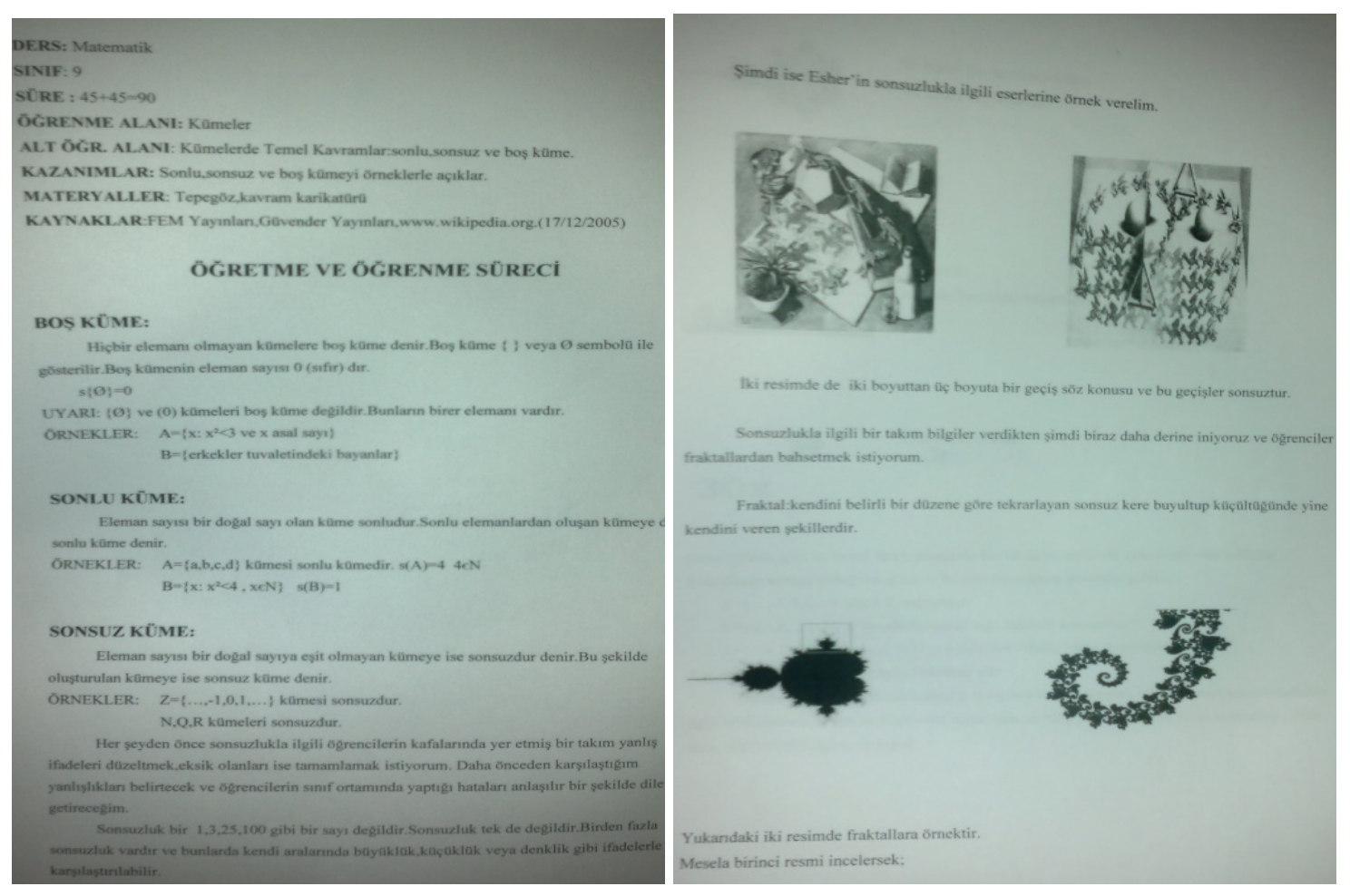

Yukarıda verilen 7 numaralı öğretim uygulamasında matematik konusu olarak kümeler, sanat konusu olarak da Escher ve fraktallar seçilmiştir (Resim 3). Çalışmada Escher'in boyutlar arası geçişi simgeleyen Kertenkeleler adlı çalışması ve fraktalların öğretim açısından matematik içeriğiyle yeterince uyumlu olmadığı görülmektedir. Sonsuz küme, genellikle sonsuzluk kavramıla ilişkilendirilen Escher'in resimleriyle desteklenerek sadece dikkat çekme yönünde kullanılmaya çalışılmıştır. Ancak bu ilişkilendirmenin öğrencilerde birtakım kavram yanılgılarına yol açacağı göz ardı edilmiştir çünkü kümenin iyi tanımlılık kavramıyla Escher’in resimlerindeki sonsuzluk kavramı çelişmektedir. Dolayısıyla sanat konusu olarak seçilen konu, matematiksel 
içerikle doğru biçimde ilişkilendirilememiştir. Bu nedenle 7 nolu öğretim uygulaması yetersiz kategorisinde değerlendirilmiştir.

\section{Öğretmen Adaylarının Ders Tasarımlarında Bir Sanat Dalı ile} İlişkilendirdiği Matematik Konuları

Öğretmen adaylarının öğretim uygulamalarında belirli bir sanat dalı ile ilişkilendirdiği matematik konularının genel durumunu betimlemek için Tablo 3 oluşturulmuştur.

Tablo 3

Belirli Bir Sanat Dalı İle İlişkilendirilen Matematik Konuları

\begin{tabular}{|c|c|c|c|}
\hline Sanat & & Matematik & \\
\hline \multirow{7}{*}{ Altın Oran } & Açılar (37) & Doğal Sayılar (41) & Kümeler $(10,22$, \\
\hline & Bağıntı (1) & Fonksiyon (4, 9, 17, 21, & 36) \\
\hline & Çokgenler $(27,34)$ & $38)$ & Limit $(3,15)$ \\
\hline & Dikdörtgen $(33,34,43)$ & İntegral (6) & Oran orant1 (32) \\
\hline & Diziler $(11,12,14,26$, & Karmaşık sayılar (2) & Reel sayılar (23) \\
\hline & 31) & Katı cisimler $(5,13,35)$ & \\
\hline & Fonksiyonlar (30) & Kümeler (7) & Simetri $(1,18)$ \\
\hline \multirow{2}{*}{$\begin{array}{l}\text { Escher ve } \\
\text { Sanatı }\end{array}$} & İntegral (25) & Limit $(8,9)$ & Yönlü açılar (37) \\
\hline & Kat1 cisimler $(5,28)$ & Paradox (26) & \\
\hline \multirow{5}{*}{ Fraktallar } & Dikdörtgen (33) & İrrasyonel sayılar (23) & Rasyonel sayılar \\
\hline & Diziler $(26,31)$ & Karmaşık sayılar (2) & $(20)$ \\
\hline & Doğal sayılar (41) & Kümeler $(7,24)$ & Reel sayılar (23) \\
\hline & Fonksiyonlar $(4,9)$ & Limit-süreklilik $(8,15)$ & Sonsuzluk \\
\hline & İntegral (25) & Logaritma (40) & $\begin{array}{l}\text { kavramı }(19,24, \\
29,41)\end{array}$ \\
\hline \multirow[t]{2}{*}{ Fibonacci } & Dikdörtgen $(34,43)$ & Diziler $(11,12,14,39)$ & $\begin{array}{l}\text { Doğal sayılar } \\
\text { (41) }\end{array}$ \\
\hline & Aç1lar (37) & Diziler $(14,26,31)$ & Kümeler $(7,10$, \\
\hline \multirow{3}{*}{$\begin{array}{l}\text { Kavram } \\
\text { Karikatürü }\end{array}$} & Bağıntı (1) & Fonksiyon $(4,17,21,30$, & $22,36)$ \\
\hline & Çokgenler $(27,34)$ & 38) & Limit $(3,15,16)$ \\
\hline & & Karmaşık sayılar (2) & İntegral (6) \\
\hline \multirow[t]{2}{*}{ Resim } & Bağıntı (1) & Katı cisimler (5) & Reel sayılar (23) \\
\hline & Diziler (14) & Oran orant1 (32) & Simetri (18) \\
\hline Mimari & İntegral (25) & Kat1 cisimler (28) & Oran orantı (32) \\
\hline
\end{tabular}

Tablo 3 incelendiğinde öğretmen adaylarının yararlandıkları sanatla ilişkili konuların; altın oran, Escher ve sanatı, fraktallar, Fibonacci dizisi uygulamaları, kavram karikatürü, resim ve mimari olduğu görülmektedir. Adayların MS kapsamında işlenen el 
sanatları ve matematik, origami-krigami, matematik ve müzik, sinema ve fotoğrafçılık gibi konulardan yararlanmadığı görülmektedir. Matematik konularının öğretiminde altın oran ve fraktallardan yararlanılan 14 konu varken, Escher ile sekiz, kavram karikatürü ile dokuz, resim ile altı, fibonacci ve mimari ile ilişkilendirilen de üç konu bulunmaktadır. Sanat ile ilişkili konuların öğretmen adaylarının ders tasarımlarında ne kadar sıklıkla yer aldığına bakıldığında şunları ifade etmek mümkündür; Altın oran 30 öğretmen aday1, Kavram karikatürü 21, Fraktallar 20, Escher ve sanat1 11, Fibonacci 7, Resim 6 ve Mimari 3 öğretmen adayı tarafından kullanılmıştır. Bu durumda en fazla yararlanılan konular altın oran ve kavram karikatürü iken en az yararlanılanların resim ve mimari olduğu görülmektedir.

Matematik konularının sanatla entegrasyonunda en çok ve en az tercih edilen konular şöyledir:

Altın oran: fonksiyonlar ve diziler (5), dikdörtgen, kümeler ve katı cisimler (3), limit ve çokgenler (2), oran-orantı, bağıntı, açılar, karmaşık sayılar, reel sayılar, doğal sayılar ve integral (1).

Escher ve sanatı: limit, katı cisimler ve simetri (2), fonksiyonlar, yönlü açılar, paradox, integral ve kümeler (1).

Fraktallar: sonsuzluk (4), diziler, limit-süreklilik ve fonksiyonlar (2), karmaşık sayılar, dikdörtgen, doğal sayılar, ondalık sayılar, logaritma, kümeler, integral, reel sayılar, karmaşık sayılar ve irrasyonel sayılar (1).

Fibonacci sayıları: diziler (4), dikdörtgen (2), doğal sayılar (1).

Kavram karikatürü: fonksiyonlar (5), kümeler (4), diziler ve limit (3), çokgenler (2), bağıntı, açılar, karmaşık sayılar ve integral (1).

Resim: Bağıntı, diziler, katı cisimler, oran orantı, reel sayılar ve simetri (1).

Mimari: İntegral, katı cisimler, oran orantı (1)

Tüm konular dikkate alındığında öğretimi hedeflenen matematik konuları çoktan aza sıralandığında ilk dördün diziler (6), fonksiyon (6), kümeler (5), limit (5); son dördün doğal sayılar (1), ondalık sayılar (1), reel sayılar (1) ve logaritma (1) olduğu görülmektedir.

Hazırlanan öğretim uygulamalarında ele alınan konuların ortaöğretim matematik ve geometri programı kapsamında tüm sınıf düzeylerine hitap ettiği görülmektedir. Örneğin; bağıntı ve kümeler konusu dokuzuncu, diziler 11., limit ve integral 12. sınıf matematik konularıyken, dikdörtgen dokuzuncu ve katı cisimler 12. sinıf konularıdır. Sayısal verilere bakıldığında da matematik konularının geometri konularına göre daha fazla kullanıldığı görülmüştür.

\section{Sonuç ve Tartışma}

Yapılan analizler sonucunda öğretmen adaylarınca hazırlanan ders tasarım örneklerinin en fazla orta, en az ise iyi kategorisinde yer aldığı görülmüştür. Dolayısıyla örneklemdeki adayların MS ilişkisine yönelik ders tasarlamada orta ve alt düzeyde kaldıkları görülmektedir. Adayların ders tasarımlarında belirli sanat konularını belirli 
(kısıtlı) matematik konularıyla ilişkilendirerek verdiği görülmüştür. Bu durumun nedeni olarak matematik konusunu somutlaştırmak ve dikkat çekmek amacıyla sanat konusunun seçilmesi düşünülmektedir. Örneğin; fraktallar konusu daha çok diziler ve sonsuzluk kavramlarına yönelik kullanılırken altın oran diziler, kümeler, fonksiyon ve özellikle dikdörtgen konularının öğretiminde kullanılmıştır (Tablo 3). Escher, gerçek hayatta imkânsız görünen resimleriyle paradox (örneğin; birbirini çizen eller resmi), boyutlar arası geçiş çalışmalarıyla ikinci ve üçüncü boyut (örneğin; kertenkeleler) ve pek çok resmiyle de limit ve sonsuzluk kavramlarını büyüleyici sanat anlayışıyla gözler önüne sermektedir (Bitlis, 2003; İlter, 2003). Dolayısıyla Escher ve sanat1; paradox, limit, simetri konularının anlatımına doğrudan bir zemin hazırlamaktadır. Sanat konularının seçiminde ve öğretime aktarılmasında o konuların öğrenme etkinliğinin temel parçası olarak kullanılması yerine daha çok görsel modelleme, genel kültüre yönelik ek bilgi verme ve kısa süreli dikkat çekme amaçlarına yönelik kullanılması, tasarımların niteliğini düşüren temel etkendir.

MS dersinde matematik ve sanat arasındaki ilişkilere yönelik geniş bir perspektif sunulmasına karşın öğretim uygulamalarında el sanatları ve matematik, origamikrigami, matematik ve müzik, sinema ve fotoğrafçılık gibi konulardan çok az yararlanıldığı ya da hiç yararlanılmadığı görülmüştür. Bu durum, öğretmen adaylarının ilişkilendirme yaklaşımlarının daha dar bir alanda kaldığını göstermektedir. Buradan hareketle öğretmen adaylarının konuları daha çok izole ederek düşündükleri, çok boyutlu ilişkiler kurmada ve bunları öğretim uygulamasına aktarmada güçlük çektikleri söylenebilir. Öğretmen adaylarının iki alanı ilişkilendirme düzeylerinin 'orta' ve 'yetersiz' olarak değerlendirildiği çalışmaların daha fazla olması, bunun temel dayanağını oluşturmaktadır.

Orta ve yetersiz düzeydeki tasarımların daha çok olmasının bir diğer sebebi de matematik ve sanatı ilişkilendirmede güçlük çekilmesidir. Bu durum kimi kez öğretmen adaylarının bazılarınca sözel olarak ifade edilmiştir. Sanat ya da sanatla ilişkili konulara yabancı olmaları ve yeni karşılaşıyor olmaları, bu zorluğun ana nedeni olarak görülebilir. MS dersi kapsamında bilgi edinilen ve deneyimlenen konuların bir öğretim uygulamasına nitelikli bir biçimde yansıtılamamasının bir diğer sebebi, matematik öğretmeni yetiştirmede problem olarak görülen, kişilerin matematiksel içerik bilgisi ile Shulman (1987)'nin “pedagojik içerik bilgisi” olarak adlandırdığı bilgiyi edinmelerindeki zorluklar olarak da görülebilir (Yüksel, 2008). Pedagojik içerik bilgisi, öğretmenlerin öğrencilerin anlayabilmesi için bir konuyu nasıl şekillendirmesi ve sunması gerektiğiyle ilgili anlayışlarıdır (Yüksel, 2008: 3). Yani, öğretmenin (öğretmen adayının) alan bilgisi ne kadar kuvvetli olursa olsun bunu alan öğretimine yansıtamayabilir. Ayrıca, kişilerin yetersiz alan bilgileri de, onları kavramsal anlamayı kolaylaştıran etkinlikten uzak tutabilmektedir (Ma, 1999, aktaran Cankoy, 2010). Bu da matematiksel kavramların kendi aralarında veya yan alanlarla ilişkilendirilmesin de sıkıntı yaşanabileceğini göstermektedir. Çalışmada adayların her ne kadar matematik alan bilgileri ölçülmese de öğretim uygulaması tasarlamada ve başka bir alanla ilişkilendirmede yaşadıkları sıkıntılardan dolayı bu kapsamda da bazı problemlerinin 
olduğu öne sürülmüştür. Bu noktada, öğretmen adaylarının öğrenimleri boyunca daha çok teorik bilgi ile donatılmalarının ve araştırma, uygulama yapsalar da sınıf içi öğretim deneyimine sahip olmamalarının önemli bir etkisinin olduğu düşünülmektedir.

\section{Öneriler}

Genellikle çoğu kimse tarafından zor ve sıkıcı olarak nitelendirilen matematiğin öğrenilmesinde disiplinler arası anlayışa gereksinim olduğu ve bu alanda öğretim uygulamalarına ihtiyaç duyulduğu bilinmektedir. Bu tür uygulamaların gerek hizmet öncesi gerekse hizmet içi çalışmalarda ele alınması gerekmektedir. Dolayısıyla matematik öğretmen adaylarının MS etkileşim alanlarına yönelik bilgi sahibi olmalarının ve bu bilgilerini öğretimsel uygulamaları planlama, tasarlama, geliştirme, uygulama ve değerlendirmede kullanabilmelerinin sağlanması gerekmektedir. $\mathrm{Bu}$ düşünceden hareketle matematik ve sanat arasındaki etkileşime yönelen bir öğrenme anlayışı gerek NCTM gerekse ülkemizdeki matematik dersi öğretim programlarında açıkça ifade edilmekte ve örneklendirilmektedir.

$\mathrm{Bu}$ çalışmanın sonuçları çerçevesinde şunu ifade etmek mümkündür: MS alanında bilgi sahibi olma ve tartışma, tek başına nitelikli öğretimsel uygulamaların tasarlanmasına yeterince katkı sağlayamamaktadır. Bu nedenle hem lisans düzeyindeki MS vb. derslerde hem de alan eğitimine yönelik diğer derslerde MS bağlantılarına dönük bilgiler, araştırmalar, tartışmalar ile doğrudan MS ilişkilerine dayanan çeşitli öğretimsel uygulamalar geliştirme, uygulama ve değerlendirme çalışmaları yararlı olacaktır. Özel olarak öğretmen adaylarının hizmet öncesi çalışmalarında öğretim uygulamaları ve özgün ders planları tasarlamalarına yönelik çalışmaların artırılması gerekmektedir. Adayların ilişkilendirme becerilerini geliştirecek çalışmalar yapılıp bu yönde desteklenmeleri sağlanmalıdır. Özellikle etkinlik geliştirme çalışmaları içerisinde MS bağlantılarına yer verilmesi, çeşitli etkinlik örneklerinin üzerinde çalışılması esastır. Aynı zamanda MS'nin etkileşimi ile ilgili özellikle ülkemizde matematik öğrenmeöğretme sürecini ele alan akademik araştırmalar sınırlı olduğundan bu alanda daha fazla araştırma yapılmalıdır. Araştırmalarda, öğretmen adaylarına gerçek sınıflarda uygulama imkânı (okul deneyimi ve öğretmenlik uygulaması gibi derslerde) verilmesi durumundaki tasarımları ve bu tasarımların öğrenci geri bildirimlerine dayalı olarak yeniden yapılandırılması ele alınabilir.

\section{Kaynakça}

Bailey, K. D. (1982). Methods of social research (2nd ed.). New York: The Free Press.

Bilgin, N. (2006). Sosyal bilimlerde içerik analizi teknikleri ve örnek çalışmalar (2. bask1). Ankara: Siyasal kitabevi.

Bitlis, B. (2003). Dikkat paradox var!, Matematik Dünyası, Klş Sayısı, 65-66.

Bixler, H. N. (1980). A group theoretic analysis of symetry in two dimensional patterns from Islamic art (Unpublished doctoral dissertation). New York University, New York.

Boakes, N. J. (2009). Origami instruction in the middle school mathematics classroom: 
its impact on spatial visualization and geometry knowledge of students. Research in Middle Level of Education Online, 32(7), 1-12.

Bora, U. (2002). Bilim ve sanatın kesiştiği nokta: Matematik ve müzik ilişkisi. Uludăg Üniversitesi Eğitim Fakültesi Dergisi, 15(1), 53-68.

Büyüköztürk, Ş. (2011). Sosyal bilimler için veri analizi el kitabı (17. baskı). Ankara: Pegem Yayıncılik.

Cankoy, O. (2010). Matematik öğretmenlerinin $\mathrm{a}^{0}, 0$ ! ve a $\div 0$ ile ilgili konu temelli pedagojik alan bilgileri. Kuram ve Uygulamada Eğitim Bilimleri, 10(2), 729-769.

Demirel, Ö., Tuncel, İ., Demirhan, C., \& Demir, K. (2008). Çoklu zeka kuramı ile disiplinler arası yaklaşımı temel alan uygulamalara ilişkin öğretmen-öğrenci görüşleri. Eğitim ve Bilim, 33(147), 14-25.

Emmer, M. (1993). The visual mind II (1st ed.). London: The MIT Press.

Farako, G., \& Francaviglia, M. (2004, September 23-24). A course of mathematics in art. Paper presented at the Applications of Mathematics to Cultural Industry Minisymposium, Venice, Italy.

Fukuda, H., Kanomata, C., Mutoh, N., Nakamura, G., \& Schattschneider, D. (2011). Polynominoes and polyiamonds as fundamental domains of isohedral tillings with rotational symmetry. Symmetry, 3, 828-851.

Graham, R. G. (1996). Implementing the connection between mathematics and art in the classroom (Unpublished master's thesis). Kean College of New Jersey, New Jersey.

Güneş, G., \& Gökçek, T. (2010, Ekim). Eğitimcilerin bakış açısıyla matematik ve sanat ilişkisi. Matematik Sempozyumunda sunulmuş sözlü bildiri, Trabzon.

Hanson, J. (2002). Improving student learning in mathematics and science through the integration of visual art (Unpublished master's thesis). Saint Xavier University, Chicago.

Heally, K. T. (2004). The effects of integrating visual art on middle school students' attitude toward mathematics (Unpublished master's thesis). University of Alaska, Anchorage.

Hickman, R., \& Huckstep, P. (2003). Art and mathematics in education. Journal of Aesthetic Education, 37(1), 1-12.

İlter, H. K. (2003). Sanatsal matematik bir biyografi. PIVOLKA-Ek, 5, 1-8.

İnel, D., Balım, A. G., \& Evrekli, E. (2009). Fen öğretiminde kavram karikatürü kullanımına ilişkin öğrenci görüşleri. Necatibey Eğitim Fakültesi Elektronik Fen ve Matematik Ĕ̈itimi Dergisi, 3(1), 1-16.

Jacobs, H. (1989). The growing need for interdisciplinary curriculum content. Interdisciplinary curriculum: Design and implementation. Alexandria, VA: ASCD.

James, C. Y. (2011). Does arts infused instruction make a difference? An exploratory study of the effects of an arts infused instructional approach on engagement and achievement of third, fourth and fifth grade students in mathematics (Unpublished doctoral dissertation). American University, Washington D.C. 
Kaplan, C. S., \& Salesin, D. H. (2004). Islamic star patterns in absolute geometry. ACM Transactions on Graphics, 23(2), 97-119.

Karaçay, T. (2000, Haziran). Matematik sanatı. Matematik Sempozyumunda sunulmuş bildiri, Ankara.

Karakuş, F. (2010). Fraktal kart etkinliğiyle fraktal geometriye giriş. İlköğretim Online, 9(1), 1-6.

Kelley, C., Jordan, A., \& Roberts, C. (2001). Finding the science in art. Journal of College Science Teaching, 31(3), 162-166.

Marino, R. (2008). Geometry in art and design (Unpublished doctoral dissertation). Colombia University, New York.

McCoy, R. (1996). A study on an integrated mathematics and art curriculum for fifth grade second language learners (Unpublished master's thesis). San Jose State University, California.

Milli Eğitim Bakanlı̆̆ı. (2009a). Illköğretim matematik dersi öğretim programı (1-5. sinıflar). Ankara: Milli Eğitim Basımevi.

Milli Eğitim Bakanlığı. (2009b). İlköğretim matematik dersi öğretim programı (6-8. sinıflar). Ankara: Milli Eğitim Basımevi.

Milli Eğitim Bakanlığı. (2009c). Ortaöğretim görsel sanatlar ve resim dersi ögretim programı (9-12. sınıflar). Ankara: Milli Eğitim Basımevi.

Milli Eğitim Bakanlı̆̆ı. (2011a). Ortaöğretim matematik dersi öğretim programı. Ankara: Milli Eğitim Basımevi.

Milli Eğitim Bakanlı̆̆ı. (2011b). Ortaöğretim geometri dersi öğretim programı. Ankara: Milli Eğitim Basımevi.

Miles, M. B., \& Huberman, A. M. (1994). Qualitative data analysis: An expanded sourcebook. California, CA: Sage.

National Council of Teachers of Mathematics. (2000). Principles and standarts for school mathematics. Reston, VA: NCTM.

Orhan, C. (1995). Matematik ve sanat. Matematik Dünyası Dergisi, 5, 21-23.

Özcan, Ö. (2002). Türk edebiyatında hiciv ve mizah yergi ve gülmece başlangıçtan günümüze. İstanbul: İnk1lâp Kitapevi.

Özkök, A. (2005). Disiplinlerarası yaklaşıma dayalı yaratıcı problem çözme öğretim programının yaratıcı problem çözme becerisine etkisi. Hacettepe Üniversitesi Eğitim Fakültesi Dergisi, 28, 156-167.

Priolo, J. (2009). Using art and mathematics together to help improve students' progress (Unpublished master's thesis). Caldwell College, New Jersey.

Shilling, A. W. (2002). Arts and young children mathematics, music and movement: Exploring concepts and connections. Early Childhood Education Journal, 29(3), 179-184.

Shulman, L. S. (1987). Knowledge and teaching: Foundations of the new reform. Harvard Educational Review, 57, 122.

Türk Dil Kurumu. (2012). TDK Büyük Türkçe Sözlük, http://tdkterim.gov.tr/bts/, (10 Aralık 2012). 
Uğurel, I., \& Moralı, S. (2006). Karikatürler ve matematik öğretiminde kullanımı. Milli Ĕ̈itim Dergisi, 170, 32- 46.

Wichmann, B. (2008). Symmetry in Islamic geometric art. Symmetry: Culture and Science, 19(2-3), 95-112.

Yıldırım, A., \& Şimşek, H. (2008). Sosyal bilimlerde nitel araştırma yöntemleri (7. bask1). Ankara: Seçkin Yayıncılık.

Yin, R, K. (1984). Case study research: Design and methods. Beverly Hills, GA: Sage Publications.

Yüksel, G. (2008). Farklı içerik bilgisi seviyelerindeki matematik öğretmen adaylarının ders planlarında gözlenen pedagojik içerik bilgilerinin incelenmesi (Yayımlanmamış yüksek lisans tezi). Gazi Üniversitesi, Ankara. 